\title{
Mapping Street Sounds in the Nineteenth-Century City: A listener's guide to social engineering
}

DOI:

10.1080/20551940.2018.1476305

\section{Document Version}

Accepted author manuscript

Link to publication record in Manchester Research Explorer

\section{Citation for published version (APA):}

Llano, S. (2018). Mapping Street Sounds in the Nineteenth-Century City: A listener's guide to social engineering. Sound Studies, (May), 1-19. https://doi.org/10.1080/20551940.2018.1476305

\section{Published in:}

Sound Studies

\section{Citing this paper}

Please note that where the full-text provided on Manchester Research Explorer is the Author Accepted Manuscript or Proof version this may differ from the final Published version. If citing, it is advised that you check and use the publisher's definitive version.

\section{General rights}

Copyright and moral rights for the publications made accessible in the Research Explorer are retained by the authors and/or other copyright owners and it is a condition of accessing publications that users recognise and abide by the legal requirements associated with these rights.

\section{Takedown policy}

If you believe that this document breaches copyright please refer to the University of Manchester's Takedown Procedures [http://man.ac.uk/04Y6Bo] or contact uml.scholarlycommunications@manchester.ac.uk providing relevant details, so we can investigate your claim.

\section{OPEN ACCESS}




\title{
Mapping Street Sounds in the Nineteenth-Century City: A listener's guide to social engineering
}

\author{
Samuel Llano
}

University of Manchester, Manchester, United Kingdom

School of Arts, Languages and Cultures, University of Manchester, Samuel Alexander Building, Oxford Road, Manchester M13 9PL

Email: samuel.1lano@manchester.ac.uk

Word Count: 6,893

Biographical note:

Samuel Llano is a Lecturer in Spanish Cultural Studies at the University of Manchester. His research examines the relationship between the music and sound cultures of Spain, France and Northern Africa, and explores music's intersections with social issues such as public hygiene and social aid. His first monograph, titled Whose Spain: Negotiating "Spanish" Music in Paris (OUP, 2012) posits that "Spanish music" of the early twentieth century is a transcultural process characterised by the ways in which Spanish composers resident in Paris (Falla, Albéniz) engaged with the "Orientalist" stereotypes and imperialist dynamics prevalent in France. In 2013, this book received the Robert M. Stevenson Award of the American Musicological Society. His second monograph, titled Discordant Notes: Marginality and Social Control in Madrid, 1850-1930 (OUP, forthcoming March 2018), analyses the ways in which street and tavern music in Madrid, as they challenged the social and economic order, triggered the development of new forms of social control. He is currently co-editing (with Tom Whittaker) a special issue of the Journal of Spanish Cultural Studies titled "Sound Cultures of Spain" that will be published in 2019. Together with Matthew Machin (Cambridge), in September 2018, Llano will start working on the ERC-funded five-year 
project "Past and Present Musical Encounters Across the Strait of Gibraltar," in which he will be Senior Researcher. 


\section{Mapping Street Sounds in the Nineteenth-Century City: A listener's guide to social engineering}

The pervasiveness of calls to study sound from an interdisciplinary perspective is both the consequence and the cause of a profound transformation in understandings of what "sound" is and does. If anything characterises "sound studies," more than any disciplinary boundaries or a defined set of methods, is an increasing consensus that sound is a transverse and complex phenomenon that cuts across disciplines, sensory experiences and cultures. Awareness of sound's transversality, however, is not a prerogative of sound studies, nor is it a recent discovery; it predates the constitution of sound studies as an academic discipline or constellation of disciplines. The most forceful attempts to come to terms with sound's transversality were arguably first manifest in a world removed from the production of knowledge. They were triggered by a perceived need to implement legal and institutional mechanisms aimed at domesticating sound, that is, at controlling the affective responses that it elicits and in which it is constituted. The following discussion is focused on the study of sound control in history and, more particularly, in the nineteenth-century city. Two types of approach have prevailed in this field of study: the drawing of historical sound maps, using digital technologies to generate data that are processed to produce visual topographies of sound practice (Cohen 2012b); and the analysis of discourse in cultural production and the media at large, including newspapers, literature, and treatises (Boutin 2015; Picker 2000; Picker 2003). These approaches, especially when used in conjunction, have brought significant insights into the ways in which the experiencing of sound in different cities finds expression through patterns of spatial distribution, and is mediated by memory and affect (Cohen 2012a). They have also contributed to exploring sound's materiality and transformative capacities, or, in other words, to explaining what sound does as opposed to what it merely represents. There is however a risk that these methods may leave out important aspects of the ways in which sound control has been used as a technology of social engineering in the past. In 
particular, analysis of nineteenth-century techniques of sound control in urban contexts reveal strategies of territorialisation and marginalisation that relied neither on visual nor verbal representation. They easily slip from attention because they do not fall within the immediate or expected remit of sound control. These techniques include the production of statistics on matters as diverse as salubrity and disability, logbooks and reports by local residents and police officers on public disorders, scientific manuals on matters such as public hygiene and crime, as well as laws, local ordinances and more casual pieces of legislation (i. e. circulars, edicts) on matters as diverse as drinking establishments, mendicancy, social aid, and public order. These methods are evidence of the rise of a scientific approach to tackling crime, insalubrity and poverty in urban contexts during the nineteenth-century. This "medicalisation of the city" (Cañedo Rodríguez 2012) prompted and guided urban reforms as important as Hausmann's Paris and the transformation of Barcelona and Madrid in the mid-nineteenth century. One of its negative consequences was the production of strict moral and social orthodoxies that divided the population into "citizens" and the "marginalised" (Cleminson and Fuentes Peris 2009). Sound control was an integral part of this redrawing of physical, ontological and psychological boundaries.

The aforementioned techniques of sound control did not necessarily require the literal use of maps, that is, of bi-dimensional representations of the urban space, in order to be effective. I would like to argue, however, that their use for the purpose of controlling sound constitutes an instance of mapping, insofar as they rest on a conception of space as the scenario of social competition and power interplay. Like Latour, I understand "mapping" in a non-literal sense, as a technology of territorial and social control that is linked to the acquisition of power through the accumulation of information on space and social practice in a few hands and locations (Latour [1990] 2011). This broader conception of sound mapping aims to follow sound in its journey across disciplines and listening cultures, as it brings together methods from a range of areas, including hygiene, social aid and acoustics. The working together of data collection and manipulation - what Latour calls "inscriptions" - alongside (pseudo-)scientific methods born out of the rise of 
medical approaches to the city, cannot be grasped through the sole use of digital sound maps nor through the analysis of discourse from the press or literature.

The following discussion, therefore, is aimed at presenting an integrative analysis of early forms of sound control that, although they did not rely on sound maps - and indeed predated their popularisation -, participated from many of the same strategies through which maps have been used to dominate space. It is my contention that the authorities of most nineteenth-century cities diversified and refined the sources and methods used to collect, organise and represent information on sound, and that this diversification and refinement were aimed at compensating for the limitations of the primitive technologies of mapping and sound recording available to them. Discussion of early or primitive sound mapping techniques is illustrated, towards the end of the article, through reference to late nineteenth-century Madrid. This choice is aimed at curbing the inertial tendency of studies on historical urban soundscapes to focus on Paris and, to a lesser extent, London and New York (Boutin 2015; Picker 2000; Picker 2003; Radovac 2015; Radovac 2011), and to continue with an emergent trend that aims to enhance the geographical scope of studies on historical urban soundscapes (Biddle and Gibson 2016; Knighton and Mazuela-Anguita 2018). By focusing on Madrid, I not only hope to shed light on an uncharted geography in sound studies. There is a chance that turning our attention towards unexplored cultures and their peculiarities could lead to the formulation of new paradigms or, at least, to raising awareness about the limitations of the existing ones. Common to many existing studies on historical urban soundscapes is an understanding of urban sound as a relatively autonomous phenomenon that, despite being integrated into the fabric of urban society, reduces the citizens' condition to that of sound producers or listeners, and overlooks the production of more complex and multifarious subjectivities. Sound control and abatement did not emerge solely out of a desire to enhance comfort and reduce sound pollution, but must be regarded, more broadly, in connection with the development of new forms of social engineering and control and, related to them, of new models of urban planning. These new forms and models were developed in response to a sentiment of crisis engendered by some of modernisation's worst effects, such as social 
inequalities, alienation, crime and violence. By enhancing our understanding of "mapping" in line with Latour's loose formulation of the term we may be able to step

more easily beyond the object/subject binary that structures dominant paradigms of sound production and perception, and to better understand the complexities and myriad ramifications of the transversality of sound.

\section{Mapping Sound(s), Building Orthodoxies}

Sound mapping does not map sounds - or at least not only sounds; it maps people and experience too. The scope of sound mapping extends to modes of listening and producing sound, as well as ways of encoding the experiencing of sound. Sound is involved in the shaping of collective emotions and the production of discourse and, through them, in generating attitudes towards social problems. Because sounding unfolds in space, the emotions and reactions provoked by sounds are also spatialised. But whereas sound, once produced, expands and aims to occupy the totality of space, the way sound-induced behaviour is ordered in space is more complex, and is subject to multiple influences that are culturally specific. Sound mapping, therefore, offers an effective if somewhat elusive means of organising experience in time and space and, in that way, of facilitating social control.

To reduce sound mapping to being a tool of social control, however, is unfair. The aim of sound mapping is arguably to identify patterns and anticipate them. Sounding operates within ecologies, resonating within mobile and interdependent structures of meaning and emotion. In urban contexts, sound ecologies are characterised by a "relative fixity" (Atkinson 2007, 1905-6). Tracking and anticipating sound patterns in the city can have positive consequences, such as reducing noise pollution to help improve the wellbeing of citizens. Sound patterns and parameters such as loudness can be modified and controlled in manifold ways and for different purposes. The use of legislation and the media establishes a regime of restrictions and deploys an array of social attitudes and 
opinions. Thus, sound mapping and control both create and depend on a system of values through which vulnerable sensitivities may be protected.

Yet, notwithstanding the potential positive effects of sound mapping, it seems difficult to deny that, at least to some extent, sound control is a tool of social orthodoxy. Sound mapping establishes a regime of priorities and a hierarchy of values. Who and what defines those values and priorities is subject to social competition, which can take the form of illegitimate appropriation of space and the manipulation of discourse. In a city, the subject is forced to position him or herself as either an insider or an outsider in relation to dominant sound patterns. These patterns structure experience, as they set or impose a rhythm that regulates the lives of citizens and fosters productivity. Sensory experience is organised into dynamic structures that filter in and out modes of sound production and listening. This osmotic, regulatory mechanism marginalises individuals and groups, because sound production and perception are linked to experience. Identifying a common enemy is often experienced as a form of relief as well as a way to deflect control from above (Girard [1982] 1986, 17-18). The urban soundscape is no exception to this dynamics of exclusion and is thus a stage for the production of displaced and fragmented subjectivities.

These considerations are important in relation to the specific problems of the nineteenth-century city. Views of the city as a den of vice and degeneration were born out of moralistic concerns expressed in Nordau's Degeneration (Nordau 1892) and Simmel's work on the metropolis (Simmel [1903] 2002). They were the flip side of the way in which various nineteenth and early twentieth-century movements and ideologies, including fascism, idealised the countryside as a repository of stability, tradition and ethnic purity (Brass 2000, 1-61). These views may seem exaggerated today, and they were formulated in a language that was laden with contemporary anxieties. But it is undeniable that the history of European cities is to a great extent marked by crime, poverty, and violence. These problems have been caused in part by natural or man-made catastrophes such as epidemics and wars, although their main causes are likely to be population growth as well as uncontrolled and irresponsible economic change. In 
response to this, local authorities and state governments have traditionally tended to implement social control measures such the passing of ordinances on hygiene and social aid, and the use of police force. More sophisticated strategies include the co-option of the media and intellectuals to mobilise public opinion. But these measures tackle the symptoms rather than the causes.

The rise of technology is enabling ever more efficient methods of tracking sound patterns in urban contexts. Yet, sound mapping is as old as humankind, and it has always been linked with some form of control. Sound mapping techniques that predate the rise of noise abatement in the early twentieth century were dependent on different modes of organising sensory experience. In the nineteenth century, sound control had not yet developed into a self-standing discipline with its own laws, and was embedded within a hierarchy of the senses. It was to a great extent regarded as an extension of public hygiene. Lawmaking in the area of hygiene developed substantially in the nineteenth century, in contrast to regulations on "noise" which, although they existed, were mainly improvisatory. I would therefore like to propose that sound control was not subordinated to the supposed prevalence of the visual, but was rather dependent on psychological and legal mechanisms developed in reaction to smell and, related to this, in response to fears of contagion.

Early sound control technologies were not based on an assessment of sound impact on the population, but on strategies of territorialisation that were designed in connection with proposals for the improvement of comfort and living conditions laid out on the pages of manuals concerned mainly with hygiene. It is significant that mention of sound was conspicuously absent from most of them. Newspapers often raised complaints by residents in which the nuisance and stress produced by street music and noises is evident. The language of law and police records, however, suggests that the public outcry over noise did not succeed in making policy makers genuinely concerned about the wellbeing of citizens. The success of noise abaters consisted in making the authorities aware of the political cost of being too tolerant to "noise." 
It is surprising the extent to which acoustic sensitivities are often underplayed, and have only recently been given serious consideration. A possible reason for this is the much discussed centrality of the visual in Western culture - a centrality that is possibly overstated, or whose limitations we may be not doing enough to expose. Studying sound in the nineteenth century is fraught with difficulties, not the least because sound recording technologies had not yet been invented, or were only incipient and restricted to minority contexts - Edison's first recording dates from 1878. Like today, sound mapping and control were underpinned by emotional responses to sound stimuli, which can be decisive in determining social attitudes towards the problems outlined above. But in order to analyse those emotions and the sounds that triggered them, we can only rely on written testimony. This may explain why sound mapping is still today so much about the visual control of space than it is about controlling the verbal narrative through which the experiencing of sound is encoded. The absence of sound recordings of nineteenth-century soundscapes means that we cannot expect to engage as closely and confidently with these testimonies as we would with contemporary ones. These difficulties notwithstanding, the analysis of early sound mapping technologies may offer perspective over the narrowness that characterises current ones, as is revealed through active online projects (Waldock 2011). Ideally, this perspective should encourage resistance towards models of city governance based on social control.

\section{Mapping, Power and Systems of Thought}

Broadly considered mapping is a technology or range of methods that configures space as the main scenario of social competition and power interplay. As I conceive of it, mapping does not always require the use of visual maps. Analysis of sound mapping gives access to systems of thought that are intimately linked to areas of broad social concern, such as hygiene, crime, poverty and social aid. Mapping is far from a science, and is underpinned by worldviews and states of opinion. According to John Short, "maps are not neutral transmitters of universal truths" but "are social constructions, fictions if you like, 
narratives with a purpose, stories with an agenda" (Short 2001, 10). Even online digital sound maps contributed to by anonymous passers-by through their phones produce and reiterate recording cultures and norms with them (Waldock 2011). McKinney argues that "in addition to charting geographic bodies, maps also express desires, conflicts and collective anxieties" (McKinney 2010, 15). They do more than that. Maps define our relationship with space and the social interactions that unfold in it, and structures experience according to worldviews.

The way in which maps express and even impose their subjectivity is far from innocuous. Bruno Latour has argued that "by working on papers alone" maps make it "possible to dominate all things, and all people" (Latour [1990] 2011, 71). Maps draw their power to convince from being mobile and immutable. They can be transported across places, and scaled up or down without their optical consistency being compromised - in other words, without losing any of the properties that make the represented object recognisable (Latour [1990] 2011, 65-66). Most importantly, the techniques of "inscription" through which maps gather and process information can be "superimposed, reshuffled, recombined and summarised" (Latour [1990] 2011, 71) in order to generate ever growing information systems. In this way, maps, and other forms of inscription, are organised in a "cascade of ever simplified inscriptions" that lead towards a "greater merging of figures, numbers and letters"; this merger is "greatly facilitated by their homogeneous treatment as binary units in and by computers" (Latour [1990] 2011, 68). The expansion of cartography from the fifteenth century onward inaugurated a new way of viewing the world and redefined global power imbalances. Maps contribute to creating centres of power and peripheries through "the capitalisation of all compatible inscriptions" in one single place (Latour [1990] 2011, 71). This makes it possible that "the few may dominate the many" (Latour [1990] 2011, 70).

Latour does not discuss sound, but his theory of inscriptions goes some way towards spelling out the ways in which sound mapping may be used as a technology of social control. One of the preconditions for the mobility and immutability of inscriptions is that they remain optically consistent as they are transported and scaled up and down (Latour 
[1990] 2011, 67). This realisation invites us to identify and explore the technologies that make "sound objects," bodies and musical practices aurally consistent and, in that way, more easily mapped and controlled. Arguably, the goal of sound control is to impose a form of aural consistency under which subjects emerge as coherent groups or entities, once their complexity is reduced and their differences mapped out. In that way, they can be fed more easily into a statistical system or other form of inscription in which they feature as a manageable category. The following discussion of nineteenth-century Madrid shows that the means employed to achieve this were varied. Alongside the collection of data on sound practices, they included social segregation, and the use of urban planning and legislation to improve hygiene. Analysis of late nineteenth-century Madrid will also show that, before the advent of digital mapping techniques and during the expansion of the written press, sound control depended to a great extent on the use of discourse and propaganda to be made effective.

\section{Hygiene, Noise and Social Segregation}

[INSERT MAP 1 HERE]

[Map 1:Carlos María de Castro's planned ensanche (Madrid: Litografía de J. Donon, 1857)

During the second half of the nineteenth century, Madrid experienced a fast but uneven modernisation that accentuated economic and cultural disparities. These contrasts gained a spatial dimension as the rising middle classes built their own segregated space. This was the Barrio de Salamanca, on the Eastern part of the planned ensanche (expansion), which begun to be built in 1860 (Carballo, Vicente, and Pallol 2013). The physical and social transformation of Madrid, like those of Paris and London, happened quickly and left an urban landscape of spatial fragmentation and social segregation. This

process was analogous to the one that Wirth characterised as an unavoidable consequence of urbanisation (Wirth 1938), albeit with peculiarities. In Madrid, segregation was not or not only - the direct consequence of its citizens' reaction to sensory stimuli, but was 
provoked deliberately, using urban planning to protect the security and comfort of the rising middle classes (McKinney 2010,23). The ensanche was primarily aimed at palliating the effects of population growth, which was mainly provoked by the steady flow of rural immigration from the $1850 \mathrm{~s}$ on. The ensanche was designed to meet the rise in demand of space, and to make the city less dense. Map 1 shows the planned ensanche marked in red. The map shows that the new city was considerably larger and had a more regular layout than the city centre. It was hoped that the ensanche would help to sanitise the streets and fight the cholera epidemics that decimated Madrid's population since the eighteenth century (Cruz 2011, 150-64). Furthermore, the grid layout used in the ensanche made it easier to police the population's activities and movements, and to maintain social order (McKinney 2010, 19-20). This task was harder to carry out in the old city centre, where the intricate and narrow streets gave shelter to fugitives.

The ensanche was by no means unique in its kind and had equivalents in Barcelona and cities in Europe, the largest and most profound one being the renovation of Paris (1853-1870) under Napoleon III. Georges-Eugène Hausmann’s design for Paris inspired architect Carlos María de Castro's ensanche. But, whereas Hausmann's plan transformed Paris deep down to its heart, the ensanche was fragmentary, partly because of the failure to execute Castro's approved plan. In addition, Castro's decision to leave the city centre untouched, although it spared a rich architectonic legacy from being wiped out, created a sharp contrast between the pre-modern and modern areas of the city, translating social differences into scars that were visible on the urban layout (Carballo, Vicente, and Pallol 2013,59-77). This peculiarity makes the study of Madrid's soundscape particularly compelling.

Castro's map was an experiment in social engineering that would outrage today. He laid out his vision in the Anteproyecto (Castro 1860). For over two hundred pages, this document makes profuse use of statistics and other inscriptions that translate fears of contagion and class intermingling. Castro intended to capitalise on those upper and middle-class sentiments to gain the Crown's support for his project - in which purpose he was successful. The main concern revealed in the project is indeed the improvement of 
hygiene in Madrid: "the rapid population growth over the past few years [...] is the cause that hygiene and salubrity in Madrid are worsening day by day" (Castro 1860, 13). Castro's aim was to provide "the high nobility and rich bankers" with the space they "so ardently desire," and in which they will be able to

erect beautiful and sumptuous palaces surrounded by elegant and flowery gardens. They will also have leafy parks that will provide them with the salubrity, comfort and peace of mind absent in their current homes, which are paltry and badly ventilated (Castro 1860, 13-14).

The reach of these reforms was not limited to the upper middle classes. Castro was aware that the "middle classes aspire to enjoy these same assets, which their fortunes can afford" (Castro 1860,14). He pledged to guarantee access to salubrity to the whole of Madrid's population (Castro 1860,131), but regarded comfort as the prerogative of the wealthy.

Castro's elitist ensanche must be understood in connection with broader conceptions of the city articulated in the nineteenth century. Hygienists and doctors designed a range of "technologies of inscription" in order to improve salubrity and reduce mortality in the cities. This "medicalisation of the city" aimed to produce "an urban map of healthy and insalubrious spaces" that cast "the slums as focuses of infection and the spread [...] of diseases [as well as] 'dangers' associated with ongoing urban transformations" (Cañedo Rodríguez 2012, 380). Fears about social disorder and the loss of their supremacy led hygienists and doctors to regard the poor as a source of physical contamination and moral degeneration. In this respect, they most likely took their cue from the rise of the social sciences and the emerging discipline of criminology. More particularly, Bénédict Morel articulated the view that moral diseases, of which alcoholism was foremost, were passed on down the generations, destroying entire families (Morel 1857, 1-47). This line of thinking prefigured a type of scientific and journalistic literature that proliferated towards the end of the nineteenth century in Spain - among other countries - and that was focused on the city. Key in sparking this pseudo-scientific production was the translation into 
Spanish of Max Nordau's influential Entartung (1892) (Degeneration) (Nordau 1902). Nordau posited that the overwhelming effect of sensory stimuli in the nerves of city dwellers was the origin of a range of moral diseases that turned cities into dens of vice (Nordau 1895, 35-42). This view was later developed by Georg Simmel, who adopted a less moralistic approach, in which a concern for the alienating effect of the city was manifest (Simmel [1903] 2002). The impact in Spain of Cesare Lombroso, arguably the most influential European criminologist of the second half of the nineteenth century, was also considerable. Lombroso defined the criminal as the product of innate and biological factors rather than environmental ones, and claimed that it was possible to identify one through his or her physical traits (Pick 1986, 66). These different influences were manifest in La mala vida en Madrid (Bernaldo del Quirós and Llanas de Aguilaniedo 1901), a product of early twentieth-century pseudo-scientific literature inflected by the rhetoric of criminology and the social sciences. This influential book laid out a taxonomy of deviant and criminal characters in Madrid, ranging from pickpockets to prostitutes and homosexuals ("invertidos"), and described in painstaking detail the hygienic deficiencies and moral shortcomings of Madrid's poorest quarters, criminalising their population. The clear-cut, manichean, binary division between right and wrong that underpins this book must be regarded in connection with the aforementioned rise of criminology in Spain, leading to the foundation of the Spanish School of Criminology in 1903 (Cleminson and Fuentes Peris 2009). Interestingly, Castro prefigured this line of reasoning when he defended his project in the interest of "public hygiene, morality and humanity" (Castro $1860,131)$.

The "medicalisation of the city," of which Castro's project formed part, used segregation, discipline and domination tactics. Its purpose was to exclude and marginalise those social groups felt to be a threat to the comfort and salubrity of the middle and upper classes (Cañedo Rodríguez 2012, 397). Castro segregated Madrid's population according to socioeconomic status. He designed an "aristocratic" quarter that "will not be affordable by the smaller fortunes" (Castro 1860, 106), and where "mutually isolated buildings" will be "surrounded by parks and gardens" (Castro 1860, 105). The 
"middle classes of Madrid's society" would live in "blocks separated by big avenues, and by squares containing gardens" (Castro 1860, 106). In addition, he planned "a great area composed of buildings designed specifically for the working classes"; they were located "in the best ventilated area of the ensanche" in order to compensate for the impact of accumulation on health (Castro 1860, 107). In sum, Castro designed an expansion of Madrid in which the wealthier would live in wider spaces and the working classes would be exposed to a greater risk of contagion. His plan did not counter prevailing views that the slums were the primary focuses of "moral diseases," but it must be conceded that he improved the living conditions of the lower classes.

Segregation, however, was not the answer to all potential threats. Castro, who was familiar with the work of contemporary hygienists, was worried that the free circulation of air could contribute to the spread of diseases (Castro 1860, 23). He thus subscribed to the theory of miasmas (Castro 1860, 75), which most hygienists upheld at the time. Castro was not alone in expressing this concern. Stallybrass and White have argued that, for all its spatial segregation, the nineteenth-century city was "shockingly promiscuous," and that "the fear of that promiscuity was encoded above all in terms of the fear of being touched" (Stallybrass and White 1986, 135). Yet, it was "the sense of smell [that] engaged social reformers" - they argue -, "since smell, whilst, like touch, encoding revulsion, had a pervasive and invisible presence difficult to regulate" (Stallybrass and White 1986, 139). Thus, despite the implementation of legal and other regulatory measures, the city "continued to invade the privatized body and household of the bourgeoisie in the form of smell" (Stallybrass and White 1986, 139). Yet, it could be argued that the spread of sound and noise was as noxious and as hard to control as that of smell. It is precisely in the context of his defence of proper ventilation that Castro makes the only reference to sound in the Anteproyecto: air - he argues - is a "revitalising agent on which the lives of all organic beings depend," and is also the "agent of combustion and sound transmission" (Castro 1860, 23).

As hygiene in the cities improved in the twentieth century, fears of contagion were gradually replaced by concerns about the uncontrolled spread of noise trough the air. The 
earliest testimonies of the authorities' inability to control noise expansion, however, are as old as cities. Hendy describes noise as a force that is "too intangible and slippery," too hard to control (Hendy 2013, 7). He has shown through a study of noise in Ancient Rome that, even though the "Roman elite" used noise control to "maintain social order," sound "travels freely through the air, disrespecting all physical or social boundaries"; and "it was precisely this promiscuous, disruptive quality that has always made it seem so dangerous to those seeking power" (Hendy 2013, 69, 84).

That sound control is linked to the attainment and preservation of power has been cogently formulated by Attali:

Everywhere, power reduces the noise made by others and adds sound prevention to its arsenal. Listening becomes an essential means of surveillance and social control ... Today, every noise evokes an image of subversion. It is repressed, monitored" (Attali 2009, 122).

The upper and middle classes in early twentieth-century Europe propped up their position in society and reinforced their sense of superiority by embracing silence as a sign of refinement. This attitude took them to dismiss the working classes as "noisy" and unrefined people (Bijsterveld 2008, 15-17, 170). Even before that, "the elite society of Restoration Madrid [1874-1936] defined itself by the exclusion and denial of all that contradicted its self-image of progress and modernity" - and this included noise (Parsons 2003, 63). This politics of silence was behind the attempts by the middle classes to establish a culture of comfort in Madrid.

\section{Sound Control in Late Nineteenth-Century Madrid}

Towards the end of the nineteenth century, Madrid was a city of "noise," at least according to many of its residents. The 1892 local ordinances were the first to stipulate explicit sound control measures by forbidding after midnight "any noise that may disturb the peace of residents, or to gather in groups to play music or serenade without 
permission from the competent authority" (Belmás 1892, 13) These regulations, however, not only did they come long after residents had started to express their anger at soundrelated nuisances in Madrid, but they did not manage to stop residents from raising complaints to the authorities. The installation of bells and organs on the facades of cinemas was a major cause of anger and disruption (AMV 1907b). ${ }^{1}$ Even though a tax was levied on these instruments, they were definitively banned in 1907 in response of the "nuisance they cause to local residents" (AMV 1907a). There were also numerous "noises" on the streets of Madrid, such as the loud cries of street vendors advertising their wares (AMV 1889). Two sound practices, however, were particularly disruptive, namely, the sounds, music and "noise" coming out of taverns at night - including the performance of flamenco -, and the music of organ grinders on the streets. The following discussion will be focused on organ grinders, as the consequences of their activity spread to a wider range of areas of social concern. Reactions to blind buskers will also be discussed, to show the extent to which disability could mediate in social perceptions of "noise."

\section{Organilleros}

The study of the social tensions embodied in nineteenth-century urban soundscapes has advanced notably thanks to the publication of work that focuses on the sound practices of marginal street dwellers. Picker's study of organ grinders in Victorian London (Picker 2000; Picker 2003, 41-81) and Boutin's study of the cries of street peddlers in Paris (Boutin 2015) are particularly revealing of the impact of street sound practices on urban sensitivities. Their work represents a compelling comparative case to analyse the situation of the street musicians from Madrid known as organilleros, who played the grind organ and, from the 1890s, the barrel piano. Like Boutin's peddlers (Boutin 2015, 7) organilleros occupied a marginal position in the city's economy as seasonal workers, and were often persecuted and scapegoated for that reason. There are close analogies between Madrid's orgsanilleros and Picker's organ grinders, insofar as both disrupted the

1 Municipal Archive

AMV referrs to the Archivo Municipal de la Villa de Madrid, Madrid's 
peace and comfort of residents. The work of Picker and Boutin offers significant insights into the impact of street sounds on the aural sensitivities of the literate middle classes as revealed through the latter's literary production and campaigns in the media. I would like to argue, however, that a more comprehensive approach is needed in order to account more fully for the transversality of sound in society. In particular, analysis of a wider range of reactions to sound-related annoyances reveals the extent to and ways in which street music was involved in the rise of comfort, the forging of middle-class consciousness,' the spread of hygiene and the protection of the work ethic; and mediated the relationship between legislation on and social attitudes towards matters as diverse as public order, crime, charity and social aid, as well as the relationship between gender and space. In addition, analysis of municipal records on police complaints by residents, social aid and disability reveal information about the whereabouts of organilleros, the types of nuisance that they caused to local residents, the language used by the latter to file complaints, and the authorities' measures to control and regulate the activity of these musicians. Madrid's municipal archives contain a wealth of records on these matters, and the scattered references to organilleros deserve full consideration.

Organ grinders made their appearance in Barcelona and Madrid in the 1850s, in a context of growing poverty. Mendicancy was forbidden in Spain since the eighteenthcentury. Poverty was seen as a godly punishment for idling, and the poor as sources of physical and moral contamination (Shubert 1991, 40). The steady arrival of rural immigrants in Madrid during the nineteenth century significantly increased pauperism in this city. The presence of the poor on the streets provoked discomfort among the rising middle-classes, not the least because they were regarded as sources of contamination in the wake of a spate of deadly cholera epidemics (Fuentes Peris 2003, 10, 135-36).

The greatest offence organ grinders were accused of is that they challenged social perceptions on poverty and mendicancy, and brought into question the principles on which the social aid system rested. In several ways, organilleros caused more unease than beggars. Organilleros undeniably performed a public service as they were paid to play at weddings, parties and other celebrations. But since they also took money from 
passers-by, they were mostly seen as beggars in disguise. They thus complicated the distinction between "real" and "fake" poor on which the state had based the rationalisation of social aid since the eighteenth century (Callahan 1971, 3-5). A Royal Order of 1745 defined the "vagrant" (vago) as the individual who plays "music and dances in the pace and manner that is now permitted by custom" (Cabrera 1998, 41). The utilitarian view of society that exudes from this testimonies was the cause that, shortly after organilleros emerged in Madrid around the mid-nineteenth century, they were the object of negative biases. In 1908 El Globo protested that

it is truly shameful to see strong, lively and healthy youngsters pulling the organillo trolley, playing this instrument and begging on the streets. No; asking for alms is for those who need them and cannot work, but not for those who, being able to work, steal the bread from those who should not be ashamed of earning it through charity. (El Liceniado Veneno 1908).

El Globo regarded organilleros as beggars in disguise and as a waste of valuable workforce.

The music of organilleros crossed many other boundaries, and challenged codes of conduct and morality. An article from 1867 complained that "there is no comparable torment" to the "noise" produced by organ grinders; this instrument disrupts the work of the "businessman," the "engineer" or the "lawyer" and runs against the work ethic (S.C. 1867). This article accused the organillero of burglary: "he steals the alms that the rich man tosses from the balcony to get rid of his [the organillero's] homicidal cantatas; he steals the businessman's workforce and the poor labourer's rest"(S.C. 1867). It is thus implied that organilleros obtained alms through coercion, and that they wasted not only their own workforce, but also that of those residents who were annoyed by their music. Animosity against them was fuelled by xenophobia - the first ones came from Italy. This sentiment is shown in a description of them as "foreigners who come to empty our pockets and fill up our heads" (S.C. 1867). 
The middle classes regarded organilleros as a threat to public order and comfort. Madrid's residents wrote to the mayor asking him to ban the public bailes (dances) at which they played, which "are a nuisance to residents" (AMV 1899); or to move these bailes to "locations removed from residential areas" (AMV 1913b). Residents complained to the authorities about the "dubious morality" of the songs accompanied by the organillo, and about the "cries and shouting [heard] at any time of the day or night" (AMV 1913a). The bailes improvised on the streets "obstruct[ed]" the "transit of people," especially in "narrow streets" (AMV 1902). Their presence could be considered "irreverent" if they stood too close to a church (AMV 1900). Their music was associated with uncontrolled sexuality. Criminologist Rafael Salillas dismissed what he called "copulation" dances such as the waltz, polka, and chotis played by the organillo (Salillas 1898, 97-98). Novelist Pío Baroja was uneasy about the "lascivious movement" of women dancing to the music of the organillo (Baroja 1910, 78).

Organilleros transgressed the psychological and cultural divide between the public and private spaces, and the gender codes on which it rested. The middle classes eagerly reinforced this divide through conduct manuals and literature, in order to justify that women remain confined to the domestic space (Aldaraca 1991). In contrast to the obedient and abnegated housewife and domestic servant described in manuals such as The Angel of the House (Sinués de Marco 1859), a source depicted a "a young 'maid' [who] cannot restrain here impulses" upon listening to the street organillo: "she lets loose whatever she is holding in her hands - even a full set of crockery - and lets her feet follow the music"; the music of the organillo - this article continued - provokes "a nervous effect that a sensitive and domestic girl cannot control" (Palacio 1888). The organillo crossed class divisions too, and raised anxieites about the blurring of class identities.

In response to these concerns, the activity of organilleros was regulated from the 1870 s on. A system of information was established in order to keep track of the times and locations at which organilleros played. Residents, the police and the media were used as sources of information on these musicians. Through this mechanism of sound mapping, 
the authorities tried to identify, anticipate and modify regular patterns in order to improve the comfort of residents. In addition to this, a licensing system and a string of regulations restricted the times and places at which organilleros were allowed to play (Sa del Rey 1909). Failure to comply with these regulations gave the police the excuse to use physical force and the authorities to abuse their power. In 1889, a campaign in the press framed organilleros for a fake murder allegedly committed in the village of Carabanchel, in Madrid's outskirts. Before news that the murder was a fake reached readers ("Sucesos de Madrid" 1889a), the authorities had profited from a window of time to detain and interrogate organilleros, and search and raid their homes ("Sucesos de Madrid" 1889b). This allowed the authorities to gather substantial information, which they used to map and control the whereabouts and movements of organilleros. During the 1890s, the successive city governors debated and disputed over the times and places at which organilleros should be allowed to play. The outcome was a stricter regime than in 1870 . Proof of the extent to which these control measures had rendered information the world of organilleros so available and precise at the turn of the twentieth century is that newspaper El Heraldo de Madrid was able to produce a detailed statistics on the number of organilleros in Madrid, as well as the times and places in which they used to play (Sa del Rey 1909). By gathering and crossing information, the authorities were able to impose serious restrictions on the activity of organilleros. If by 1870 , complaints indicate that they played all over the old and new parts of the city without time restrictions, by the 1920s, their presence was reduced to a few merenderos (built-up picnic halls), at which they only played during daytime (Insua 1922). This control was exercised without the use of modern-day maps, but nevertheless using techniques of inscription and crossing information in ways that remind of Latour's conception of mapping.

Attitudes towards organilleros varied over time. Once considered a foreign, picturesque presence that added exotic colour, by the 1920s they became fully assimilated into the local and national imaginaries. They were even regarded with nostalgia, or as an autochthonous bulwark against the "invasion" of jazz and "foreign" music (Tartarín 1922; Insua 1922). 


\section{Blind Buskers}

Records on disability and social aid reveal information about another type of musician, the blind busker, whose fate was linked to that of the organillero, although not in a straightforward way. Blind musicians, who mostly played guitar or the violin, were allowed to play on the streets only because they could not be turned into valuable workforce. As in England and other European countries, the workhouse system in Spain was designed to keep the poor away from the streets for reasons of public morality, as well as to prevent the spread of epidemics, most especially cholera. Workhouses were a means to manage the poor, not to eradicate poverty (Driver 1993, 3). The workhouse system followed a utilitarian principle: all members of society must contribute to its advancement as productive assets. Should they fail to produce or to follow the workhouse's strict discipline and regulations, they will be harshly punished. In the workhouse, the blind were unlike most other inmates, in that they were unable to produce goods that could then be sold. According to the categories used in social aid in Spain from the late eighteenth century, they were considered to be real poor, deserving of the state's protection. For purposes of decorum, and to prevent the Catholic Church used indiscriminate alms-giving as a way to advance their position in society - the Church presented alms-giving as a source of salvation (Callahan 1971, 2-3) -, the authorities required blind beggars to play an instrument. That way, assistance to blind beggars by the passers-by was presented as a reward rather than as a charitable act.

The myriad records on the blind at the Municipal Archives in Madrid reveal files on permissions granted or denied to blind musicians to play on the street. The blind sought the support of the Centre for the Protection and Instruction of the Blind (1894) to help them write and put forward their requests for permission to play, and to certify that they were unable to perform any "useful" activity. The blind did not gain enough recognition to deserve that their right to play music on the street be enshrined by law. As their presence on the street became regular, however, perceptions of their activity improved at the expense of that of organilleros. The latter were increasingly regarded as fully ablebodied usurpers of the space that should be granted to their disabled counterparts - as 
shown above (El Liceniado Veneno 1908). It is significant that no complaints were raised by residents about the music of the blind - although the political and morally dubious nature of some of the romances they sung raised some controversy (Fernández 2000).

The case of blind musicians shows that, although their presence on the street had a specific type of impact on aural sensitivities, their activity fit neatly into existing categories of the poor, unlike that of organilleros. The study of blind musicians also reveals that debates on the meaning and purpose of charity and social aid affected the spatial distribution and mapping of street music and the urban soundscape.

\section{Conclusions: Mapping Noise}

The above discussion shows that, however intimately sound mapping and control are associated with power, they both require the complicity and collaboration of citizens. Because the soundscape is contributed to from all corners of society sound control is not the prerogative of social or political élites. As sound unfolds in space, it engages listeners, who are not passive receptors, but actively create, appropriate and reconfigure “acoustic territories" (Labelle 2010). If, as Attali argues, listening is "an essential means of surveillance and social control" (Attali 2009, 122), it must be concluded that listening on the street is a mechanism of mutual surveillance. Because listening is ubiquitous, sound control is dislocated and atomised. In the city, physical and material bodies are both transmitters and producers of sound. The distinction between listening subjects and resounding objects is thus blurry, and sound control hard to map. Yet, not every individual, group or institution has the same capacity to survey. Some accumulate or produce more inscriptions and act as centres of power (Latour [1990] 2011, 71). They

display an enhanced capacity to control through listening that, in extreme situations, may resemble Foucault's panopticon (Foucault 1975).

The relationship between sound control and power is complex, as the values and patterns of behaviour that they try to protect are in almost perpetual shift. Sound control does not only depend on the capacity to gather information about sounds, but also on the 
ability to manipulate and capitalise on the perception that certain sounds are more acceptable or agreeable than others, which are in turn perceived as being disruptive and unpleasant. Through this type of manipulation it is possible to engage listeners into surveying and reporting on certain sound practices - such as disruptive night "noises" or loud organilleros. The choice is mediated by "moral" dilemmas, such as the one resulting from the intersection between the work ethic and Catholic conceptions of charity, at which crossroads lay judgement passed on the organillero.

The most determining factor behind perceptions that certain sounds are appropriate, however, is the position of sound practices relative to the patterns and rhythms of the urban soundscape. According to Atkinson, urban sound ecologies are defined by a "spatial and temporal ordering of the urban soundscape" that "is often programmed" and "regularised" (Atkinson 2007, 1906). Even as sounds "collide and fade in occasionally unpredictable, multiple or purposeful ways" - he continues - a "patterning and persistence" prevails (Atkinson 2007, 1905). Because this relative fixity is not achieved spontaneously, and is reinforced in the interest of productivity, hygiene and comfort through various forms of regulation, the sounds and musical practices that fall out of this order gain a particularly disruptive quality. They consequently tend to be regarded as "noise." Bailey's definition of noise as "sound that is out of place" (Bailey 1996, 50) aptly illustrates this semiotics. It must be noted, however, that it is not only the sounds themselves that fall out of place, but the people that identify with them, or that are associated with them more or less arbitrarily, too. Khan has thus argued that "it is only because certain types of people are outside any representation of social harmony that their speech and other sounds associated with them are considered to be noise" (Kahn 1999, 47). Conversely, most of the time, the individuals and groups whose sounds and musical practices are regarded as "noise" are marginalised. The patterning of the urban soundscape is not fully fixed, however, and, as it fluctuates, it filters sounds, musics and people in an out of it. The politics of difference and marginalisation discussed above is thus subject to pressures and alterations of different kinds. 
Sound control lies at the hands of those who control the narrative of how information on sound is meant to be read. Not surprisingly Latour regards "one of the most important advantages" of inscriptions that they can "be be made part of a written text" (Latour [1990] 2011, 69). ${ }^{2}$ In nineteenth-century Madrid, the narratives that guided the mapping of sounds were mainly articulated around the binary sound/noise, whose two terms are related in complex ways. The experiencing of noise is structured by two types of argument, namely, that "noise perception is subjective and related to a specific historical context"; an that "for a sound to qualify as noise, it must lack syntax an be disorderly, unregulated, unrhythmical, and discordant" (Boutin 2015, 3, 5). Marie Thompson has described this tension as one between subject-oriented and object-oriented conceptions of noise: both are either too vague or too restrictive because they either fail to recognise that there may be specific qualities that make noise "noisy," or because they disregard "how, where and by whom [sounds] are experienced" (Thompson 2017, 4). Both approaches are based on the assumption that "noise" is negative. This was the prevailing view in nineteenth-century Madrid, as the above discussion has shown. Through a cogent analysis of noise's transversality in society, Thompson proposes to "move beyond this 'aesthetic moralism"' and to embrace "noise as a productive, transformative forcerelation and a necessary component of material relations" (Thompson 2017, 3). Yet, in order to do this, I argue, it is necessary to undo the processes through which "noise" has been configured as a negative force through history. Analysis of nineteenth-century Madrid shows that the distinction between "noise" and "sound" in that context was used to establish and redraw ontological as well as spatial boundaries, and to redefine or consolidate social and moral orthodoxies. During this process, people were pulled into and pushed outside of citizenship's perceived boundaries. Conversely, sound mapping spatialised the distinction between sound and noise, helping to visualise it and, therefore, making it easier to naturalise and to convince with. Atkinson describes the footprint of urban sound ecologies as an "unseen city" that nevertheless has "profound physiological $[\ldots]$ and political [...] consequences" (Atkinson 2007, 1906). The purpose of sound 2

Emphasis in the original 
control in Madrid was to make the confines and internal structure of this "unseen city" coincide with segregated urban plans such as Castro's ensanche, to pave the way for the rise of comfort and hygiene. The example of organilleros and taverns, however, indicates that sound practice does not conform to those structures and boundaries and aspires to override them, thus resisting sound control. From the tensions between sound control and resistance we might learn to interrogate and question current forms of social control that take sound at their centre, and that exploit dominant paradigms of sound production and perception.

\section{References}

Aldaraca, Bridget. 1991. El Ángel del Hogar: Galdós and the Ideology of Domesticity in Spain. Chapel Hill, NC: University of North Carolina Press.

AMV. 1889. 7-485-32, Expediente promovido por varios vecinos de la calle de la Mada y Mesonero Romanos contra las voces de varios dueños de puestos de pregonar sus mercancías.

—_- 1899. 11-483-81, Expediente relativo a que se prohíba un baile que se pretende establecer en un solar de la calle de la Puebla.

—_- 1900. 11-483-167, Expediente en virtud de instancia de varios vecinos pidiendo quen o se permita un baile frivólico en la Plaza de la Cebada frente a la Iglesia de Nuestra Señora de Gracia.

—_—. 1902. 14-16-33, Expediente relativo al abuso que cometen los industriales instalando veladores en las puertas de sus establecimientos, $y$ los vecinos estableciendo salones de bailes en la vía pública durante las noches de verbena. 
- - . 1907a. Expediente de instancia de D José Campos solicitando permiso para que pueda hacer funcionar el órgano que tiene situado en el Cinematógrafo de Lavapiés.

-——. 1907b. Expediente relativo a instancia del dueño del Cinematógrafo de la calle de Alcalá esquina a la de Núñez de Balboa pidiendo permiso para que funcione el órgano que tiene situado en aquel.

- - 1913a. 19-442-63, Expediente dictando varias medidas de policía relativas al estacionamiento de pianos de manubrio, apertura de calas, puestos de refrescos y cumplimiento del art. 27 de las Ordenanzas.

———.1913b. 19-443-11, Expediente adoptando disposiciones acerca de la instalación de bailes en las verbenas.

Atkinson, Rowland. 2007. "Ecology of Sound: The Sonic Order of Urban Space." Urban Studies 44 (10). Sage Publications Sage UK: London, England: 1905-17.

Attali, Jacques. 2009. Noise: The Political Economy of Music. Minneapolis; London: University of Minnesota Press.

Bailey, Peter. 1996. "Breaking the Sound Barrier: A Historian Listens to Noise." Body \& Society 2 (2): 49-66.

Baroja, Pío. 1910. Aurora Roja. Madrid: Renacimieno.

Belmás, Mario. 1892. Comentarios a las Ordenanzas Municipales de Madrid. Madrid: José Perales y Martínez.

Bernaldo del Quirós, Constancio, and José María Llanas de Aguilaniedo. 1901. La Mala vida en Madrid: Estudio psico-sociológico. Madrid: B. Rodríguez Serra.

Biddle, Ian, and Kirsten Gibson, eds. 2016. Cultural Histories of Noise, Sound and Listening in Europe, 1300-1918. London: Routledge. 
Bijsterveld, Karin. 2008. Mechanical Sound: Technology, Culture, and Public Problems in the Twentieth Century. Cambridge, Mass.: MIT Press.

Boutin, Aimée. 2015. City of Noise: Sound and Nineteenth-Century Paris. Urbana: University of Illinois Press.

Brass, Tom. 2000. Peasants, Populism and Modernism: The Return of the Agrarian Myth. London; Portland, OR: F. Cass.

Cabrera, Pedro José. 1998. Huéspedes del Aire: Sociología de las personas sin hogar en Madrid. Madrid: UPCO.

Callahan, William J. 1971. “The Problem of Confinement: An Aspect of Poor Relief in Eighteenth-Century Spain." The Hispanic American Historical Review 51 (1): 124.

Cañedo Rodríguez, Montserrat. 2012. “La ciudad medicalizada: epidemias, doctores y barrios bajos en el Madrid moderno." Journal of Spanish Cultural Studies 13 (4): 372-407.

Carballo, Borja, Fernando Vicente, and Rubén Pallol. 2013. El ensanche de Madrid: historia de una capital. Madrid: Catarata.

Castro, Carlos María de. 1860. Memoria Descriptiva del Ante-Proyecto de Ensanche de Madrid. Madrid: Imprenta de D. José C. de la Peña.

Cleminson, Richard, and Teresa Fuentes Peris. 2009. '“La mala vida': Source and Focus of Degeneration, Degeneracy and Decline." Journal of Spanish Cultural Studies 10 (4): 385-97.

Cohen, Sara. 2012a. "Bubbles, Tracks, Borders and Lines: Mapping music and urban landscape." Journal of the Royal Musical Association 137 (1). Taylor \& Francis: $135-70$. 
——_. 2012b. "Live Music and Urban Landscape: Mapping the beat in Liverpool." Social Semiotics 22 (5). Taylor \& Francis: 587-603.

Cruz, Jesús. 2011. The Rise of Middle-Class Culture in Nineteenth-Century Spain. Baton Rouge: Louisiana State University Press.

Driver, Felix. 1993. Power and Pauperism: The workhouse system, 1834-1884. Cambridge: Cambridge University Press.

El Liceniado Veneno. 1908. “Curiosidades. Leyes filarmónicas.” El Globo, January 26.

Fernández, Pura. 2000. "El estatuto legal del romance de ciego en el siglo XIX: a vueltas con la licitud moral de la literatura popular." In Palabras Para el Pueblo: Aproximación general a la Literatura de Cordel, vol. I, edited by Araceli Godino López, Pilar Martínez Olmo, Carmen Ortiz García, and Cristina Sánchez Carretero, 71-120. 2000: CSIC.

Foucault, Michel. 1975. Surveiller et punir: naissance de la prison. Paris: Gallimard.

Fuentes Peris, Teresa. 2003. Visions of Filth: Deviancy and Social Control in the Novels of Galdós. Liverpool: Liverpool University Press.

Girard, René. (1982) 1986. The Scapegoat. Translated by Yvonne Freccero. Baltimore: The Johns Hopkins University Press.

Hendy, David. 2013. Noise: A Human History of Sound and Listening. London: Profile.

Insua, Alberto. 1922. “La España pintoresca de Gautier.” La Voz, May 29.

Kahn, Douglas. 1999. Noise, Water, Meat: A History of Sound in the Arts. Cambridge, Mass.: MIT Press.

Knighton, Tess, and Ascensión Mazuela-Anguita. 2018. Hearing the City in Early Modern Europe. Turnhout: Brepols. 
Labelle, Brandon. 2010. Acoustic Territories: Sound Culture and Everyday Life. New York; London: Bloomsbury Academic.

Latour, Bruno. (1990) 2011. “Drawing Things Together." In The Map Reader: Theories of Mapping Practice and Cartographic Representation, edited by Martin Dodge, Rob Kitchin, and Chris Perkins, 65-72. John Wiley \& Sons.

Llano, Samuel. 2017. “The Sacred in Madrid's Soundscape: Toward an Aural Hygiene, 1856-1907." In The Sacred and Modernity in Urban Spain: Beyond the Secular City, edited by Antonio Córdoba and Daniel García-Donoso, 1-20. New York: Palgrave Macmillan.

- - . 2018. Discordant Notes: Marginality and Social Control in Madrid, 1850-1930. New York: Oxford University Press.

McKinney, Collin. 2010. Mapping the Social Body: Urbanisation, the Gaze, and the Novels of Galdós. Chapell Hill: University of North Carolina Press.

Morel, Bénédict. 1857. Traité des Dégénérescences physiques, intellectuelles et morales de l'espèce humaine. Paris: J. B. Baillière.

Nordau, Max. 1892. Entartung. Berlin: C. Duncker.

———. 1895. Degeneration. New York: D. Appleton \& Company.

———. 1902. Degeneración. Edited by Nicolás Salmerón. Madrid: A. Marzo.

Palacio, Eduardo de. 1888. “Organillos.” La Risa, January 15.

Parsons, Deborah. 2003. A Cultural History of Madrid: Modernism and the Urban Spectacle. Oxford; New York: Berg.

Pick, Daniel. 1986. “The Faces of Anarchy: Lombroso and the Politics of Criminal Science in Post-Unification Italy." Past and Present 21 (1): 60-86. 
Picker, John M. 2000. “The Soundproof Study: Victorian Professionals, Work Space, and Urban Noise." Victorian Studies 42 (3): 427-53.

__—. 2003. Victorian Soundscapes. Oxford \& New York: Oxford University Press.

Radovac, Lilian. 2011. “The 'War on Noise': Sound and Space in La Guardia's New York." American Quarterly 63 (3). The Johns Hopkins University Press: 733-60.

- - - 2015. "Muting Dissent: New York City's Sound Device Ordinance and the Liberalization of the Public Sphere." Radical History Review 2015 (121). Duke University Press: $32-50$.

S.C. 1867. “Música callejera.” La España Musical, January 10.

Sa del Rey, Enrique. 1909. “Los pianos de manubrio.” El Heraldo de Madrid, July 4.

Salillas, Rafael. 1898. Hampa: El delincuente español. Antropología picaresca. Madrid: Librería de Victoriano Suárez.

Short, John R. 2001. Representing the Republic: Mapping the United States, 16001900. London: Reaktion Books.

Shubert, Adrian. 1991. "'Charity Properly Understood': Changing Ideas About Poor Relief in Liberal Spain." Comparative Studies in Society and History 33 (1): 3655.

Simmel, George. (1903) 2002. “The Metropolis and Mental Life." In The Blackwell City Reader, edited by Bridge Gary and Sophie Watson. Oxford; Malden, MA: Wiley-Blackwell.

Sinués de Marco, Pilar. 1859. El ángel del hogar: obra moral y recreativa dedicada a la mujer. Madrid.

Stallybrass, Peter, and Allon White. 1986. The Politics and Poetics of Transgression. Ithaca, NY: Cornell University Press. 
“Sucesos de Madrid”. 1889a. La Época, March 22.

-__. 1889b. La Época, April 20.

Tartarín. 1922. “'Souper-chotis' en el Dancing Bombi." La Libertad, September 13.

Thompson, Marie. 2017. Beyond Unwanted Sound: Noise, affect and aesthetic moralism. New York \& London: Bloomsbury.

Waldock, Jacqueline. 2011. "SOUNDMAPPING: Critiques and reflections on this new publicly engaging medium." Journal of Sonic Studies 1 (1).

Wirth, Louis. 1938. "Urbanism as a Way of Life." American Journal of Sociology 44 (1): 1-24. 